$\underline{\underline{\beta}}=$ 圆

\title{
Study of the exogenous hormonal regulation of leaf senescence in two millets, Setaria italica, 1. and Pennisetum typhoides, burm
}

\author{
Mamata Mahapatra, K. Bijay Kumar, B. K. Mohanty* \\ P.G. Department of Botany and Biotechnology, Khallikote University, Berhampur-760001,ODISHA,INDIA \\ *Corresponding author E-mail: mohantysir57@yahoo.com
}

\begin{abstract}
The present project is aimed at studying the exogenous regulation of leaf senescence in two millets i.e. Setaria italica, L. and Pennisetum typhoides Burm. The present study is confined to the study of excised leaf senescence by using growth regulators as the exogenous agents. Attached leaf study was avoided for the reason that preliminary experiments showed insensitiveness of the leaves of these two millets to growth regulators in the attached condition. In this study three growth regulators were selected, each from three major groups. Benzimidazole (BZI) represented cytokinins and indole acetic acid represented the auxins and $\mathrm{GA}_{3}$ represented Gibberelic Acid. In the present investigation, a significant negative correlation between RNA loss and RNase activity was found in both S.italica and P.typhoides. This suggests RNase like chlorophyllase responsible for bio-molecular breakdown. DNase activity was stable, it's activity increasing either in the first $72 \mathrm{~h}$ or up to the end of the incubation, but DNase activity decreased with time. Thus there was no correlation between the two. Acid phosphatase activity did not show any correlation with the established parameters of senescence, thus in both the plants the activity of the enzyme cannot be treated as an indicator of senescence. Among the two pyrophosphatases, alkaline enzyme showed a parallelism with the changes in chlorophyll and can be used as a reliable indicator of the process. On the other hand acid inorganic phosphatase activity increased during the incubation, but had no significant relation with other senescence related changes, suggesting more investigations to ascertain the role of acid inorganic pyrophosphatase.
\end{abstract}

Keywords: Enzymes; Millets; Senescence; Hormone.

\section{Introduction}

Reports on the activity of the enzyme during senescence are controversial. While some found no correlation between the enzyme activity and chlorophyll changes (Holden, 1974; Sudhakar et al, 1991), others stressed the importance of the enzyme in senescence. Ellsworth et al., 1976; Moll et al., 1978; Sabater and Rodriguez et al., 1987; Garcia, and Galindo, 1991; Majumdar et al., 1991; Drazkiewicz and Zbighiaw, 1992). Dephytylation of chlorophyll as an early event of senescence has been investigated in the relevant years (Amir et al., 1986, 1987; Thomas 1987, et al., 1989).

Different types of proteases such as neutral alkaline and acid proteases are well marked during leaf senescence (Balz, 1966; Martin and Thimann, 1972) and the study on these has not yet taken a complete form.

RNase activity increases during leaf senescence (Bagi and Farkas, 1967; Lewington et al.. , 1967; Udvardy et al., 1967; Truelson, 1967; Mc Hale and Dove, 1968; Sodek and wright, 1969; Deleo and Sacher, 1970; Upadhyaya et al. , 1985, Brady, 1988; Balnk et al. , 1991. But the rise of RNase was not observed in both attached and detached leaves of certain plants (Srivastava and Ware, 1965). The enzyme acid phosphatase is used as a marker of lysosome in animal tissue (Beevers, 1976). This enzyme is detected in chloroplasts and suggestions are there that the enzyme may be involved in the degradation of the later (Balz, 1966). There is unanimity of opinion concerning the role of enzyme (Balz, 1966; Sodek and, Wright, 1969; Deleo and Sacher, 1970; Hodge and sacher, 1975;
Parida and Mishra, 1980; Kenis and Trippi, 1982; Huang and kao, 1991) and certain reports suggest involvement of two acid phosphatases (Sodek and Wright, 1969; Parida and Mishra, 1980). Some suggest this enzyme to be wound induced where as others suggest a de novo synthesis. The possibility that the enzyme maybe released from a bound form cannot be ruled out. These aspects prove that the knowledge about this enzyme is still incomplete.

Pyrophosphate is released in different biosynthetic pathways. Pyrophosphatases hydrolyze the pyrophosphates and by measuring the relative levels of inorganic pyrophosphates, attempts have been made to measure the biosynthetic capacity of leaf during development and Senescence. This is accomplished to the role of acid and alkaline inorganic pyrophosphatase during senescence (Rauser, 1971; Kar and Mishra, et al, 1981; Sen et al., 1984; Lin and Kao, 1990 a,b).

\section{Materials and methods}

\subsection{Experimental material}

Graded seeds of Pennisetum typhoides Burm. and Setaria italica L were obtained from Agricultural Research station, Ratnapur in Ganjam district. The seeds were sown in small seed bed plots (1 X $1 \mathrm{~m} 2$ ). The plants were grown under natural conditions till the $4 / 5$ th day and the second leaves of these plants were used as the experimental material. 


\subsection{Selection of effective test chemical concentration}

Leaves were collected, washed and randomized and floated in a range of concentration of each chemical both in the dark and under illumination. The chlorophyll content of these leaves was measured $48 \mathrm{~h}$ after incubation. From the texture of the leaves the toxicity of the chemical was assessed (loss of texture and development of dark patches was treated as a toxic response).Basing on the chlorophyll content of the leaves, the effective concentrations were chosen (Mahapatra et al, 2015).

Three growth regulators, one from each major group (cytokinins, gibberellins and auxins), were tested for their efficiency in preventing chlorophyll loss. The optimum concentration of the cytokinin was $0.1 \mathrm{mM}$ and IAA did not show any chlorophyll retention at very low concentration but with the increase in concentration, there was a corresponding rise in chlorophyll in leaves in the dark (up to certain concentration). The optimum concentrations chosen for both GA3 and IAA were $0.5 \mathrm{mM}$.

\subsection{Incubation}

The leaves were detached from the 6/7 day, old plants, randomized and leaf samples weighing ca $100 \mathrm{mg}$ fresh weight were floated in petridishes $(15 \mathrm{~cm}$ diameter) containing $50 \mathrm{ml}$ solution of the test chemicals. As the experiments with the experiments with the excised leaves were carried out both in the dark and under illuminated conditions, two sets of petridishes were incubated separately in the dark or under illumination $(20 \mathrm{Wm}-2)$ at RT under aseptic conditions. Leaves floated in distilled water served as controls for both dark and light.

\subsection{Selection of effective light Intensity}

Visual changes were observed in the leaves within $24 \mathrm{~h}$ of floating in the dark. As the lower intensities were less effective and the higher ones possibly caused photo-bleaching effects, $20 \mathrm{~W} \mathrm{~m} \mathrm{2}$ was chosen as the optimum intensity for further experiments Excised leaves were collected, washed, randomized and leaf samples weighting ca $200 \mathrm{mg}$ fresh weight were floated in petridishes containing distilled water. The petri dishes were incubated in the dark or under different intensities of continuous light $(10,20,30$, $40,50,70,100,200 \mathrm{~W} \mathrm{~m} \mathrm{-2).} \mathrm{For} \mathrm{the} \mathrm{purpose} \mathrm{of} \mathrm{providing} \mathrm{differ-}$ ent light intensities, white light from TL 4OW/54 fluorescent lamps of Philips (India) along with $25 \mathrm{~W}$ incandescent lamp were used and the chlorophyll content was measured $48 \mathrm{~h}$ after incubation.

\subsection{Estimation of enzyme activity}

The enzyme activities Ascorbic acid oxidase, Chlorophyllase, Acid protease.Alkaline protease, RNase, DNase, Acid inorganic pyro- phosphatase, Acid phosphatase, alkaline inorganic pyrophosphatase in the excised leaves of Pennisetum typhoides Burm. and Setaria italica were estimated following the methods described by Mahapatra(1992).

\section{Statistical treatment:}

For all the data, deviations from means have been indicated in the form of standard errors. In a number of graphs, the points plotted are either overlapping or remain very close, hence, the standard error values have not been shown in the graph to avoid clumsiness and confusion. Wherever necessary, students t-test' were performed.

\section{Results}

\subsection{Changes in acid phosphatase activity (fig. no.01-04)}

The activity of the enzyme acid phosphatase increased considerably up to $48 \mathrm{~h}(220.5 \%)$. There was a sharp decline in the enzyme activity during the post $48 \mathrm{~h}$. By $72 \mathrm{~h}$ the enzyme activity was lower than the initial and further decrease was observed during the last $24 \mathrm{~h}$. An almost similar trend was observed under illumination. Among the three growth regulators, GA3 was the only one that could retain the same enzyme activity and the trends in enzyme change were to some extent different from others. The effects of IAA closely followed GA3 but the values in BZI were lower than the controls throughout the experiments.

Growth regulators could not change the trends in enzyme activities and there was no consistency in the relative action of the enzyme.

\subsection{Changes in chlorophyllase activity (fig. no.05-08)}

There was a slow and gradual rise in the enzyme activity till $72 \mathrm{~h}$. At $72 \mathrm{~h}$ the rise was $59 \%$ over the initial value and was followed by a decline bringing the levels to $132 \%$ by the end of the experiment. A trend similar to dark incubation was exhibited in the illuminated leaves but the post $72 \mathrm{~h}$ decline was not seen. The rise was $32 \%$ over the controls at $72 \mathrm{~h}$ which rose to $42 \%$ by the end of the experiment.

All the growth regulators increased the Chlorophyllase enzyme activity with time, but in GA3 and IAA treated leaves there was a post $72 \mathrm{~h}$ decline like the controls, a trend which was not evident in BZI treated leaves. BZI treated leaves showed a continuous rise in the enzyme activity till the end of incubation where it was $139 \%$ of the initial activity.

All the growth regulators increased the Chlorophyllase enzyme activity slowly and gradually with time. All the hormones were almost equally effective and unlike dark incubation there was no post $72 \mathrm{~h}$ decline either in the controls or in response to any other treatment.

\subsection{Changes in RNase activity (fig. no.09-12)}

The activity of RNase was different under the dark incubation and illumination. In the dark incubated controls, the enzyme activity increased during the first $48 \mathrm{~h}$, where it became $76 \%$ higher than the initial activity. But in the post $48 \mathrm{~h}$ period the enzyme activity experienced a continuous increase in the enzyme activity with time and by the end of the experiment the increase was $179 \%$ over the initial activity.

All the growth regulator treatments checked the rise in RNase activity during the first $72 \mathrm{~h}$ of incubation, though there was an inconsistency in the effect of growth regulators on the whole.IAA seemed most effective among the three growth regulators.

All the growth regulators increased the RNase enzyme activity to a considerable extent. BZI was most effective and caused $250 \%$ rise in enzyme activity over the initial activity. In this respect IAA and GA3 were close i.e. they caused $184 \%$ and $194 \%$ rise in enzyme activity.

\subsection{Changes in DNase activity (fig. no. 13-16)}

DNase activity increased with time under dark incubation and illumination. However, the dark incubated controls experienced a mild post $72 \mathrm{~h}$ fall (15\%). At $96 \mathrm{~h}$ the enzyme activity was $121 \%$ of the initial activity in contrast to $152 \%$ in the corresponding illuminated controls.

Except IAA, all other growth regulators caused an increase in the DNase enzyme activity in the first $72 \mathrm{~h}$, then a decline was evident in the last $24 \mathrm{~h}$ of the experiment. In BZI and GA3 treated leaves the enzyme activity at $96 \mathrm{~h}$ were $114 \%$ and $117 \%$ of the initial activity respectively. The IAA treated leaves exhibited a gradual increase in enzyme activity resulting an increase of $19 \%$ over the initial activity at $96 \mathrm{~h}$.

The growth regulators caused an increase in the DNase enzyme activity. BZI treated leaves exhibited rise in enzyme activity up to $72 \mathrm{~h}$, but it experienced a mild fall in the last $24 \mathrm{~h}$ of the experiment. In GA3 treatments unlike BZI and IAA treatments a post 48 
$\mathrm{h}$ decline in enzyme activity was observed which again increased in the last $24 \mathrm{~h}$ of incubation.

Changes in Acid inorganic pyro-phosphatase activity (Fig. No.1720).

In the dark, the activity of Acid inorganic pyro-phosphatase increased during the first $24 \mathrm{~h}$. This was followed by a decrease in next $24 \mathrm{~h}$ but finally there was again an increase in enzyme activity till the end of incubation. At $96 \mathrm{~h}$ there was a $95.2 \%$ increase in enzyme activity over the initial. Trends similar to dark incubation were observed under illumination where the final activity (at $96 \mathrm{~h}$ ) was $114.3 \%$ over the initial activity.

In all the growth regulator treatments the pattern of change in enzyme activity was similar to that of controls. The difference was only in the magnitude in increase. BZI treated leaves showed an increase of $138 \%$ in the enzyme activity over the initial activity by the end of dark incubation. In GA3 and IAA treated leaves this level was $133.3 \%$ and $109.5 \%$ respectively.

As in the dark the growth regulators increased the activity of enzyme over the controls. However the magnitude of their effect was higher. There was no change in the pattern of enzyme activity.

\subsection{Changes in alkaline inorganic pyro-phosphatase activity (fig. no.21-24)}

In the dark incubation there was a slow and gradual decline in the activity of alkaline inorganic pyro-phosphatase with time. At $96 \mathrm{~h}$, the activity was only $32.4 \%$ of the initial activity. Under illumination the same declining trend was evident. However the rate of decline was slow compared to the dark treatments. At $96 \mathrm{~h}$ the enzyme activity was $43 \%$ of the initial.

All the growth regulators could check the decrease in enzyme activity to some extent throughout the experiment. BZI treated dark incubated leaves at $96 \mathrm{~h}$ showed $57.45 \%$ enzyme activity against $32.4 \%$ activity observed in the corresponding controls. GA3 and IAA also had some effect in checking the rate of decline resulting in retention of $43 \%$ and $50.3 \%$ of initial enzyme activity respectively by the end of the experiment.

All the growth regulators caused retention of enzyme activity under illumination. Their effects were quantitatively higher than the dark incubations. In contrast to the $57.45 \%$ retention in the dark incubation, BZI under illumination caused $62.6 \%$ retention of enzyme activity at $96 \mathrm{~h}$. GA3 and IAA treated leaves at $96 \mathrm{~h} . \mathrm{GA} 3$ and IAA treated leaves at $96 \mathrm{~h}$ exhibited $57.4 \%$ and $59.7 \%$ retention of enzyme activity which was higher compared to the corresponding values in the dark incubation. This suggests that the light had an enhanced effect in retaining the enzyme activity.

\subsection{Changes in ascorbic acid oxidase activity (fig. no.25- 28)}

Ascorbic acid oxidase activity increased gradually up to $72 \mathrm{~h}$ both in dark incubated and illuminated controls. At $72 \mathrm{~h}$ it was $216.2 \%$ over the initial enzyme activity in dark treatments. During the post $72 \mathrm{~h}$ period the activity declined showing a difference of $31 \%$. The illuminated leaves showed an increase in enzyme activity of $193 \%$ over the initial activity at $48 \mathrm{~h}$, which remained stable during the next $24 \mathrm{~h}$ resulting in $285.2 \%$ of initial enzyme activity at the end of the experiment.

At the first $24 \mathrm{~h}$ the Ascorbic acid oxidase activity in all the growth regulator treatments became more than double of initial activity which still increased up to the end of the experiment. At $96 \mathrm{~h}$ the enzyme activity in BZI treatments became four times as that of initial activity compared to $231.5 \%$ and $254.6 \%$ rise over initial activity in IAA and GA3 treated leaves respectively.

An increasing trend of Ascorbic acid oxidase activity was clearly evident in all the three growth regulator treatments under illumination. But in contrast to dark incubation in BZI treated leaves a post $72 \mathrm{~h}$ fall was noticed. At $72 \mathrm{~h}$ the enzyme activity was $377.7 \%$ of the initial activity in BZI treated leaves which was lowered to $362.5 \%$ in the last 24 hours of the experiment. Though BZI was most efficient in the first $24 \mathrm{~h}$ of the experiment, at the end of the experiment GA3 became most efficient causing $385.6 \%$ of the initial enzyme activity which is almost $100 \%$ more than the corresponding controls.

\subsection{Changes in acid protease activity (fig. no.29-32)}

Acid Protease activity increased by $73 \%$ during the first $24 \mathrm{~h}$ in the dark. This rise was followed by a decline till the end of the experiment. At $96 \mathrm{~h}$ the activity was $8 \%$ lower than the initial. The trends under illumination were almost similar.

The growth regulators had no significant effect on the changes on the Acid Protease enzyme activity. The action of BZI was slightly different from other hormones quantitatively.

Time course change in the Acid Protease enzyme activity under illumination was almost identical to dark incubated leaves. No hormone could alter the changes in enzyme activity to any significant extent under illumination.

\subsection{Changes in alkaline protease activity (fig. no.33-36)}

Alkaline protease activity increased with time both under dark incubation and illumination. However under dark the increase in enzyme activity up to $72 \mathrm{~h}$ was followed by a post $72 \mathrm{~h}$ decline. At $96 \mathrm{~h}$ the enzyme activity was $168 \%$ and $226 \%$ of the initial in dark and light incubation respectively.

In the dark incubation alkaline protease activity increased with time in all the growth regulator treatments. Thus the hormones had no significant effect on the pattern of time course change. However the growth regulators prevented the post $72 \mathrm{~h}$ decline. Thus there was a continuous rise in the activity of alkaline protease in hormone treatments. But the rise lowered the extent of increase during the first $72 \mathrm{~h}$ of incubation. They also prevented the post 72 $\mathrm{h}$ decline in enzyme activity. The ultimate rise was minimum in BZI treated leaves followed by IAA and GA3.

All the growth regulators under illumination checked the rise in alkaline protease activity except at $72 \mathrm{~h}$ where the activities were almost closer to the controls; the activity of the enzyme in hormone treated leaves was always lower throughout the experimental schedule.

\section{Discussions}

Chlorophyll depletion is the most striking change during senescence (Beevers, 1976) and the enzyme chlorophyllase may be responsible for such a loss. Till 1980 no biological role was assigned to the enzyme (Simpson et al., 1976). Rudiger et al,(1980) concluded that chlorophyllase is involved only in the breakdown of chlorophyll.

Ascorbic acid oxidase activity increased with time but a mild post $72 \mathrm{~h}$ fall was noticed in both $S$. italica and P. typhoides, with an exception to light treatment of excise $P$. typhoides continuous rise was observed. Thus it is difficult to comment on the nature of the enzymes and its involvement in senescence. More investigations are needed to confirm conclusion drawn by using the said chemicals with other plant species.

The acid and alkaline pyrophosphatases are involved in various metabolic pathways (Naganna and Sripathi, 1954; Naganna et al., 1955a; Simmons and Butler, 1969). But limited work done on the change in these two enzymes in senescing leaf tissue provide conflicting results. Kar and Mishra (1975) went to the extent the activity of considering alkaline pyrophosphatase as one of the indicator of leaf senescence. Hence, this pair of enzymes need special attention till some meaningful conclusion is drown regarding their role in the process of senescence.

Phosphate is the key compound in bioenergetics and hence the enzymes involved in phosphate metabolism play a vital role in the plant metabolism. Study of phosphatase is usually confined to only the acid phosphatase as there is no report regarding the presence of alkaline pyrophosphatases in higher plants. 
There are two types of RNases both capable of hydrolyzing RNA. This makes the problem still critical (Beever, 1976). The activity of DNase increases during senescence but work done on this enzyme is very limited (Srivastava and ware, 1965; Simon, 1967; Kumar and Khan, 1984; Meyer and Wagner, 1986).

Increase in protease activity is also exhibited during senescence (Anderson and Rowan, 1965; Beevers, 1968; Kar and Mishra, 1977; Peoples and Dalling 1988; Vander Valk and vanloon, 1988). But in most of the cases no correlation was observed between proteolysis and protease activity (Anderson and Rowan, 1966). A significant negative correlation between RNA loss and RNase activity was found in both S.italica and P.typhoides. This suggests RNase like chlorophyllase responsible for bio-molecular breakdown (Woolhouse, 1968; De Jong, 1972).

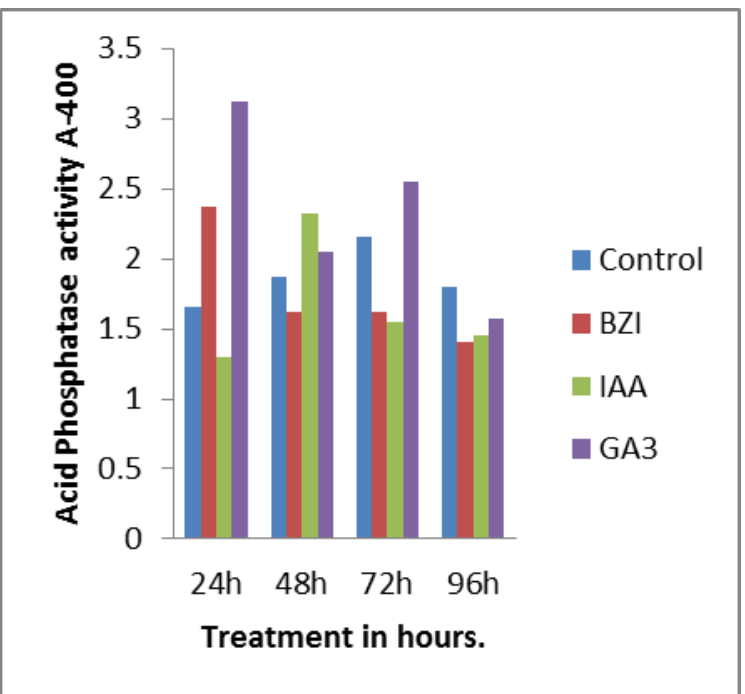

Fig. 1: Effect of Growth Regulators on Changes in Acid Phosphatase Activity in Excised Setaria italica L. Leaves During Senescence in Dark.

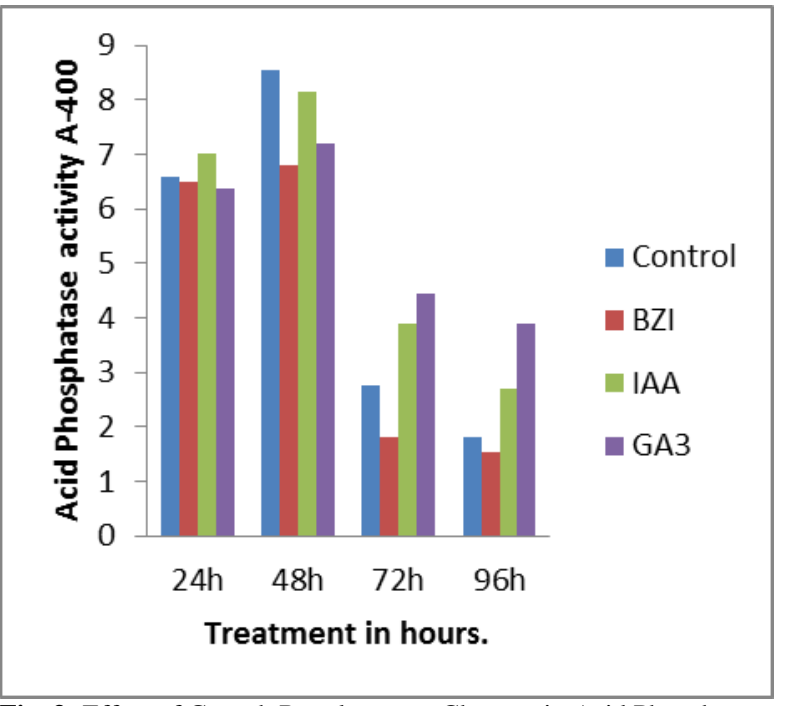

Fig. 3: Effect of Growth Regulators on Changes in Acid Phosphatase Activity in Excised Pennisetum typhoides Burm. Leaves During Senescence in Dark.
DNase activity was stable, it's activity increasing either in the first $72 \mathrm{~h}$ or upto the end of the incubation, but DNA content decreased with time. Thus there was no correlation between the two. Acid phosphatase activity did not show any correlation with the established parameters of senescence, thus in both the plants the activity of the enzyme cannot be treated as an indicator of senescence. Among the two pyrophosphatases, alkaline enzyme showed a parallelism with the changes in chlorophyll and can be used as a reliable indicator of the process. On the other hand acid inorganic phosphatase activity increased during the incubation, but had no significant relation with other senescence related changes, suggesting more investigations to ascertain the role of acid inorganic pyrophosphates.

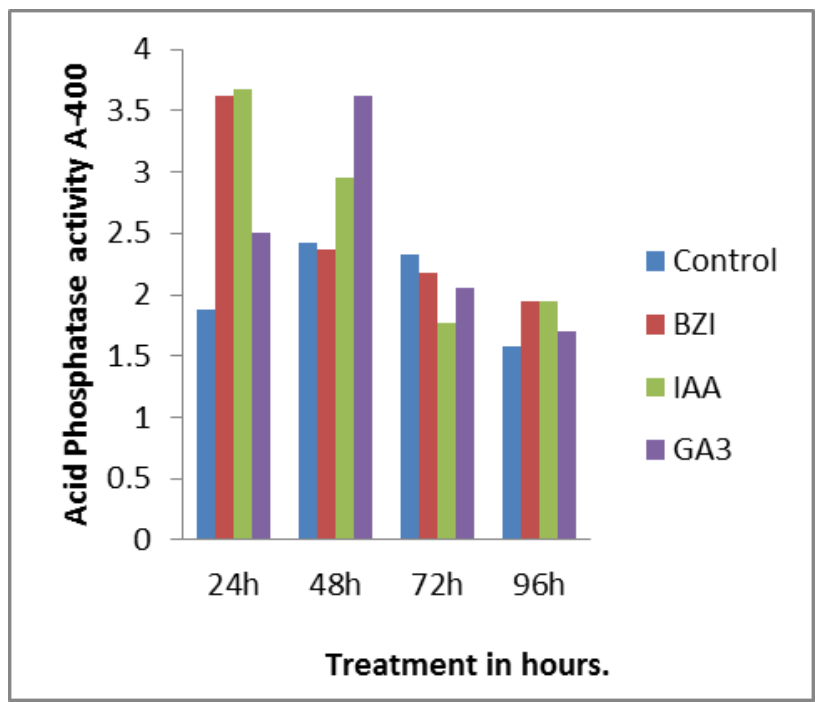

Fig. 2: Effect of Growth Regulators on Changes in Acid Phosphatase Activity in Excised Setaria italica L. Leaves During Senescence in Light.

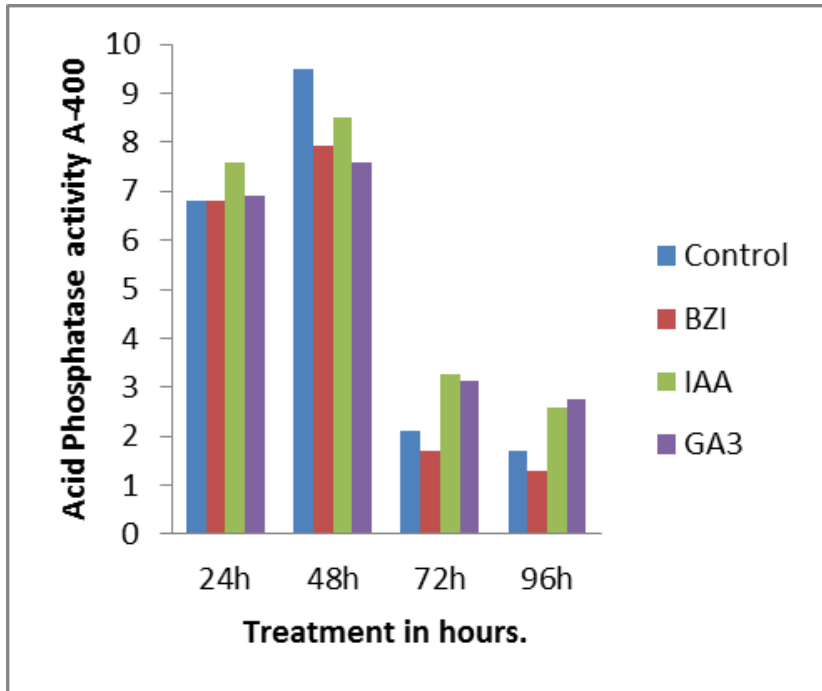

Fig. 4: Effect of Growth Regulators on Changes in Acid Phosphatase Activity in Excised Pennisetum typhoides Burm. Leaves During Senescence in Light. 


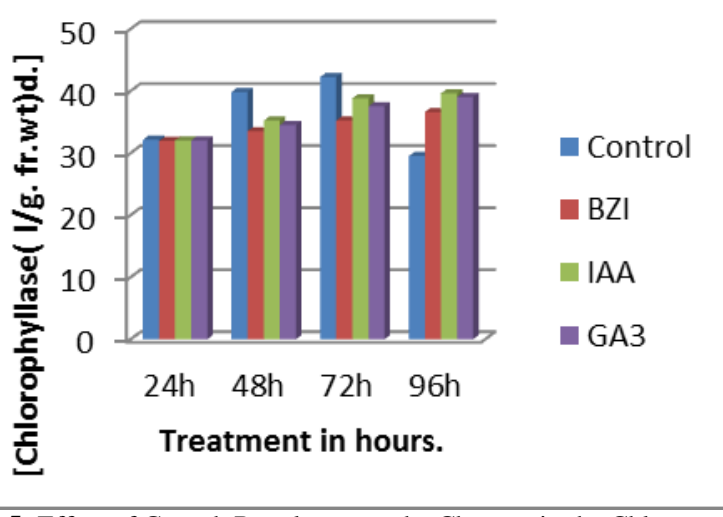

Fig. 5: Effect of Growth Regulators on the Changes in the Chlorophyllase Activityof Excised Leaves of Setaria italica L.During Senescence in Dark.

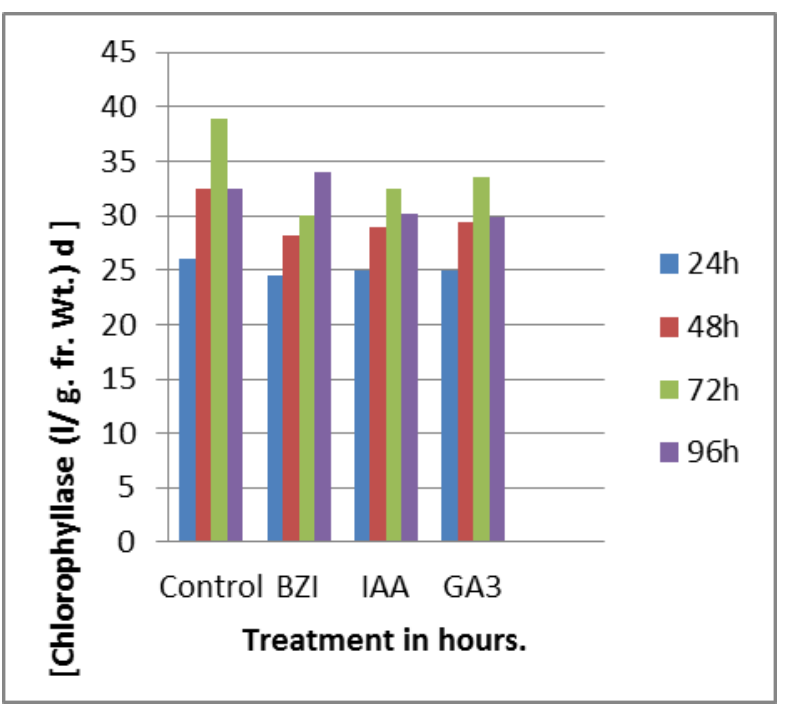

Fig. 7: Effect of Growth Regulators on the Changes in the Chlorophyllase Activity of Excised Leaves of Pennisetum typhoides Burm. During Senescence in Dark.

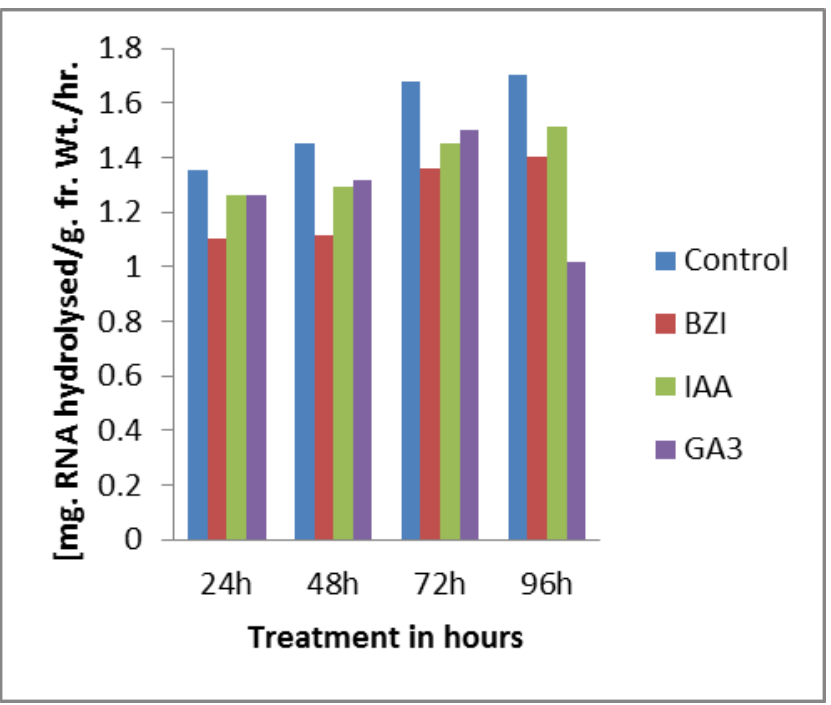

Fig. 9: Effect of Growth Regulators on Changes in Rnase Activity in Excised Setaria italica L. Leaves During Senescence in Dark.

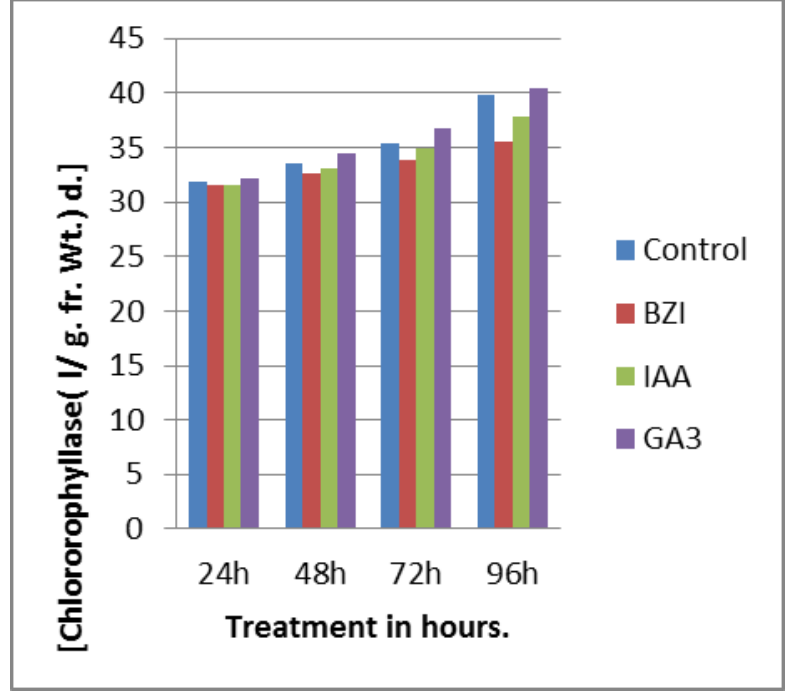

Fig. 6: Effect of Growth Regulators on the Changes in the Chlorophyllase Activity of Excised Leaves of Setaria italica L. During Senescence in Light.

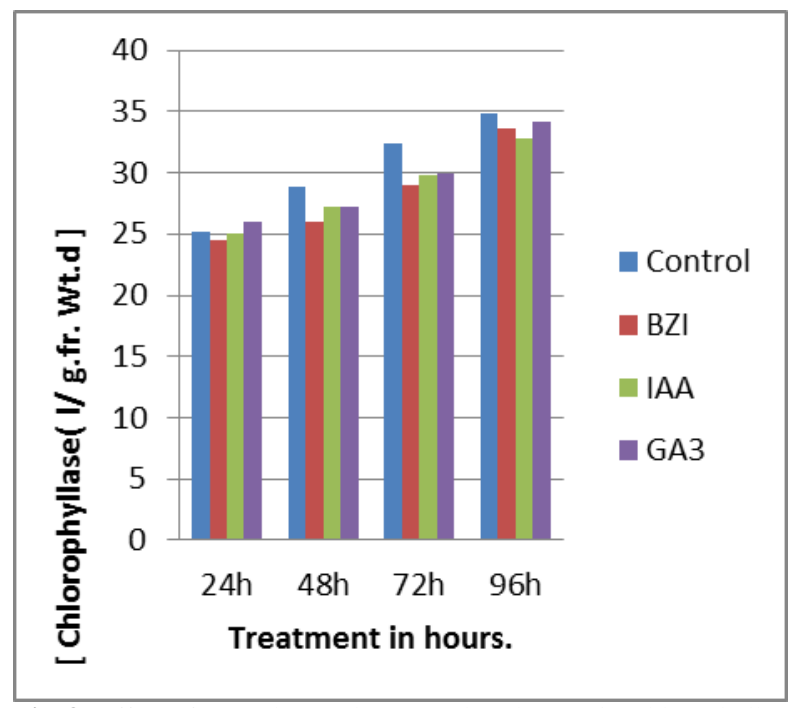

Fig. 8: Effect of Growth Regulators on the Changes in Chlorophyllase Activity of Excised Leaves of Pennisetum typhoides Burm. During Senescence in Light.

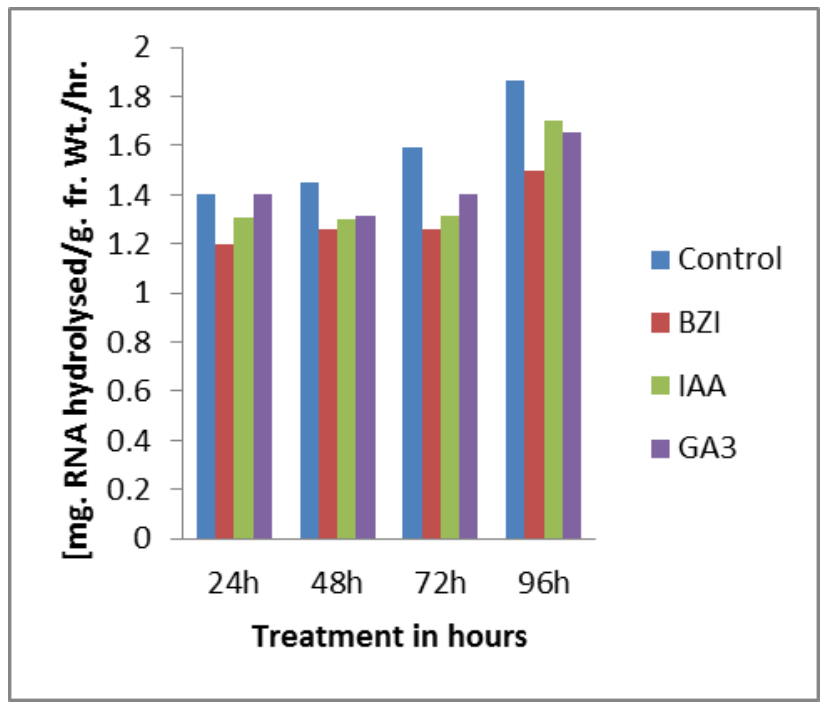

Fig. 10: Effect of Growth Regulators on Changes in Rnase Activity in Excised Setaria italica L. Leaves During Senescence in Light. 


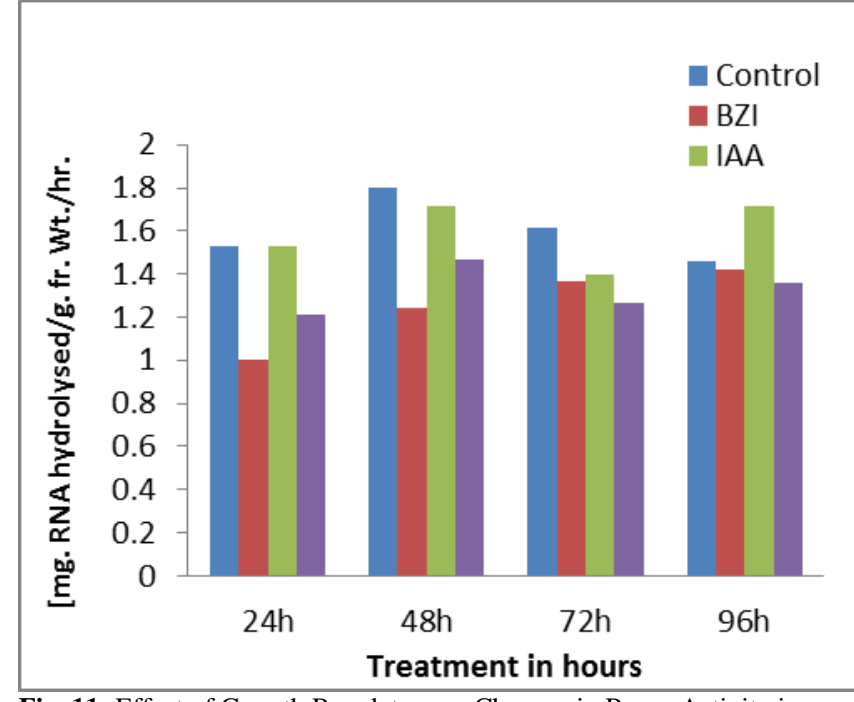

Fig. 11: Effect of Growth Regulators on Changes in Rnase Activity in Excised Pennisetum typhoides Burm. Leaves During Senescence in Dark.

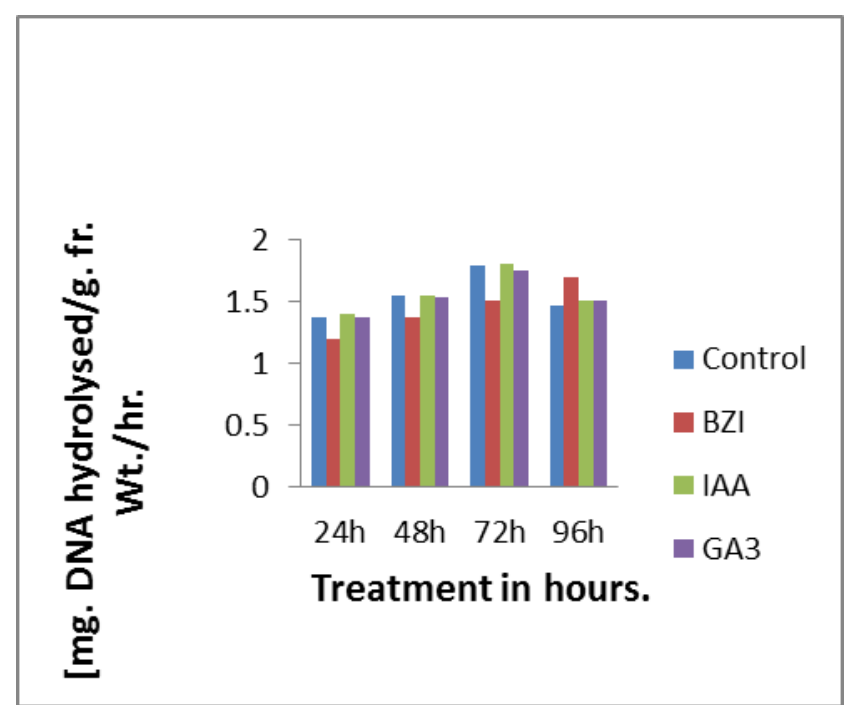

Fig. 13: Effect of Growth Regulators on Changes in Dnase Activity in Excised Setaria italica L. Leaves During Senescence in Dark.

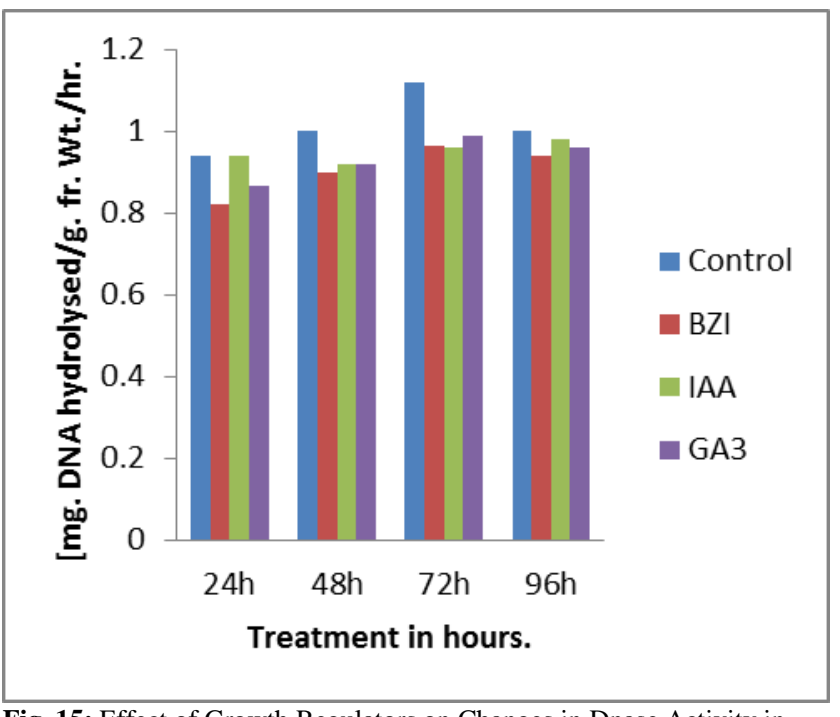

Fig. 15: Effect of Growth Regulators on Changes in Dnase Activity in

Excised Pennisetum typhoides Burm. Leaves During Senescence in Dark.

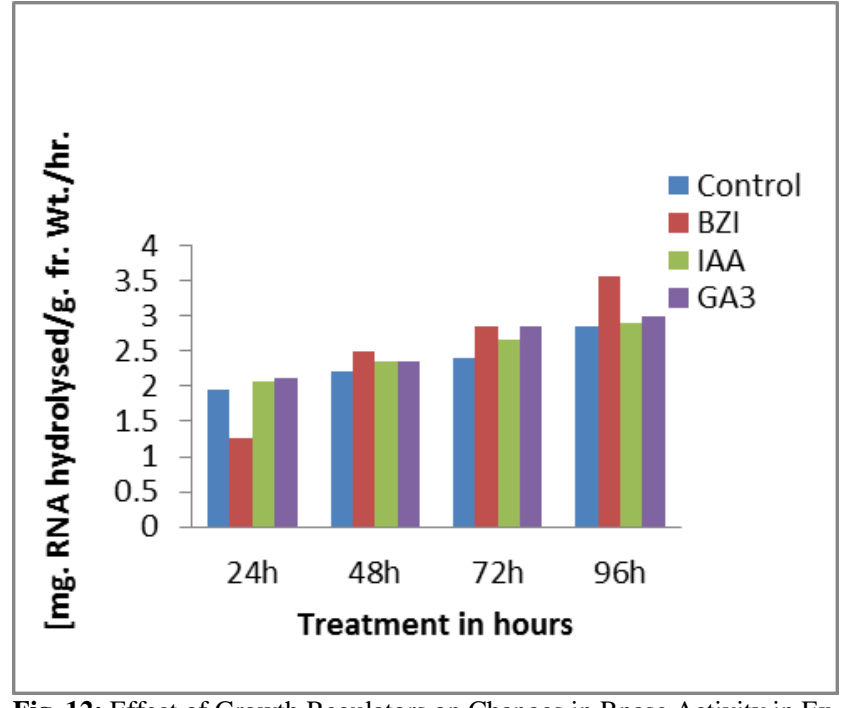

Fig. 12: Effect of Growth Regulators on Changes in Rnase Activity in Excised Pennisetum typhoides Burm. Leaves During Senescence in Light.

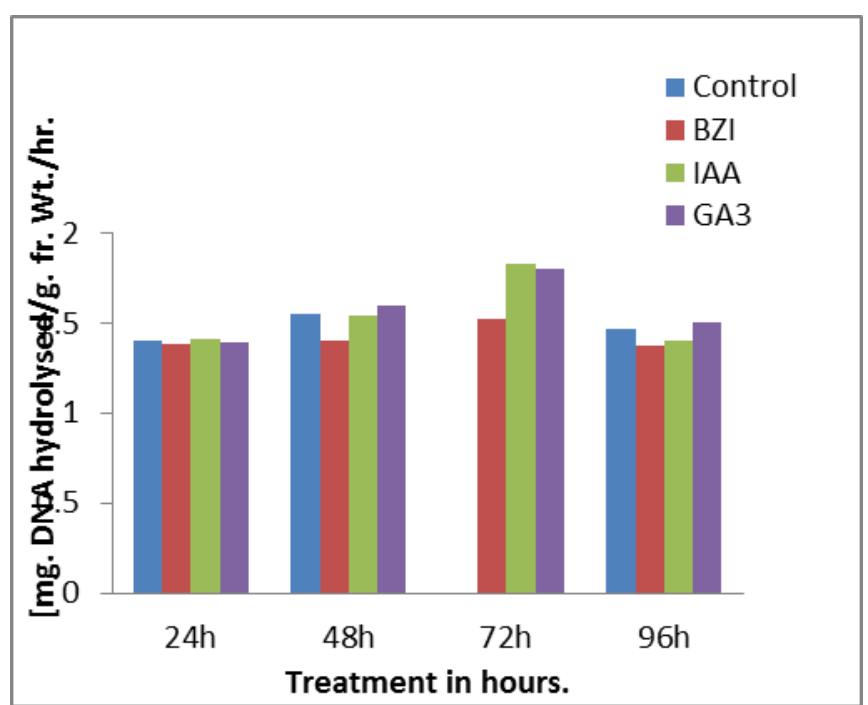

Fig. 14: Effect of Growth Regulators on Changes Dnase Activity in Excised Setaria italica L. Leaves During Senescence in Light.

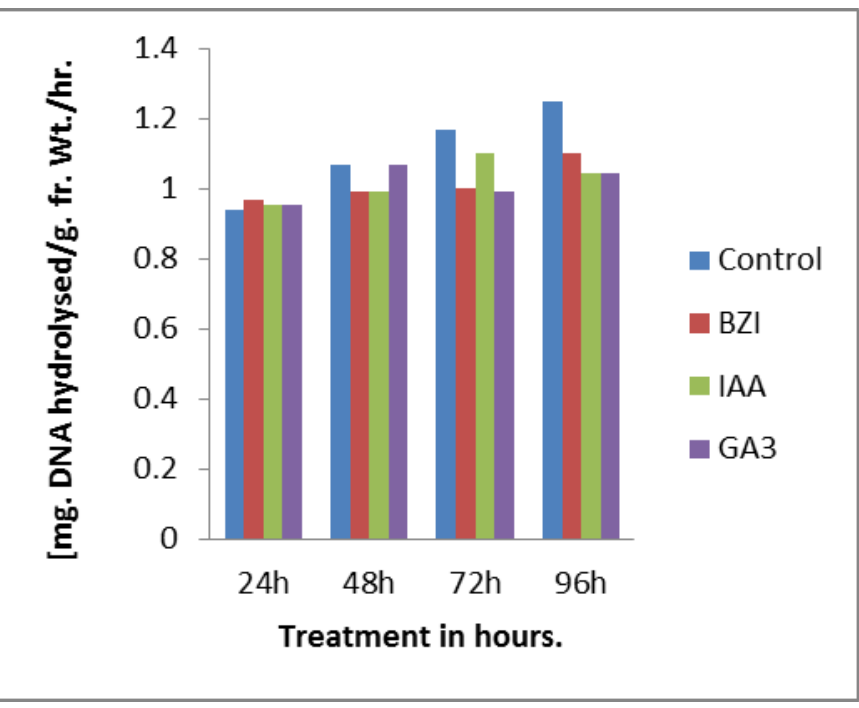

Fig. 16: Effect of Growth Regulators on Changes in Dnase Activity in Excised Pennisetum typhoides Burm. Leaves During Senescence in Light. 


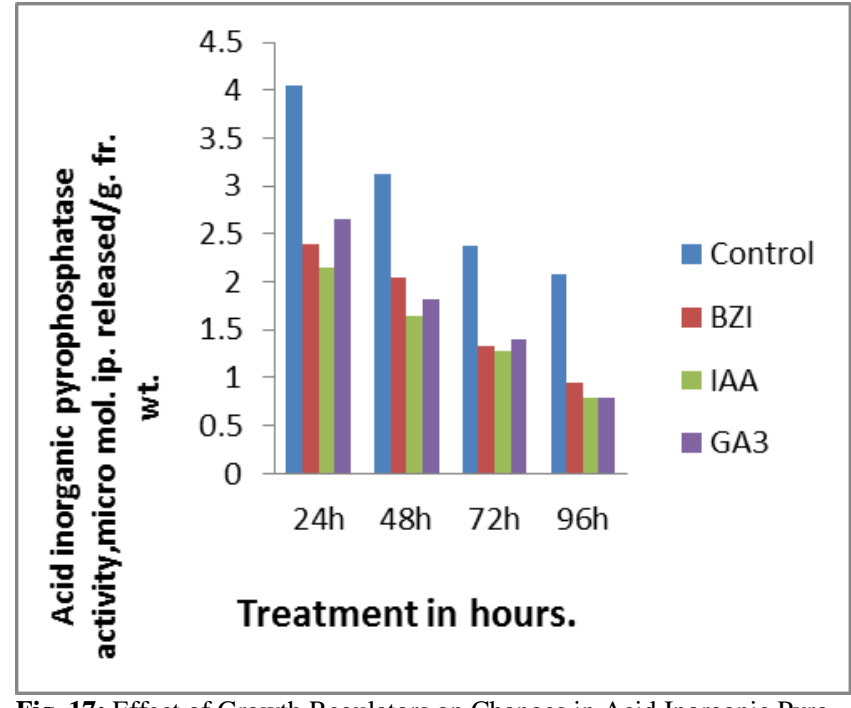

Fig. 17: Effect of Growth Regulators on Changes in Acid Inorganic Pyro Phosphatase Activity in Excised Setaria italica L. Leaves During Senescence in Dark.

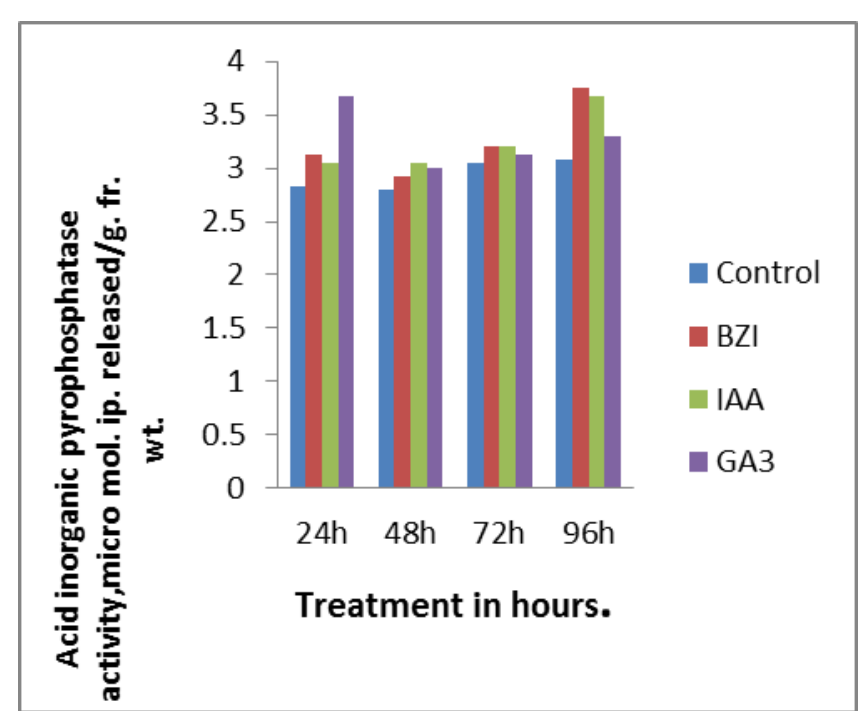

Fig. 19: Effect of Growth Regulators on Changes in Acid Inorganic Pyro Phosphatase Activity in Excised Pennisetum typhoides Burm. Leaves During Senescence in Dark.

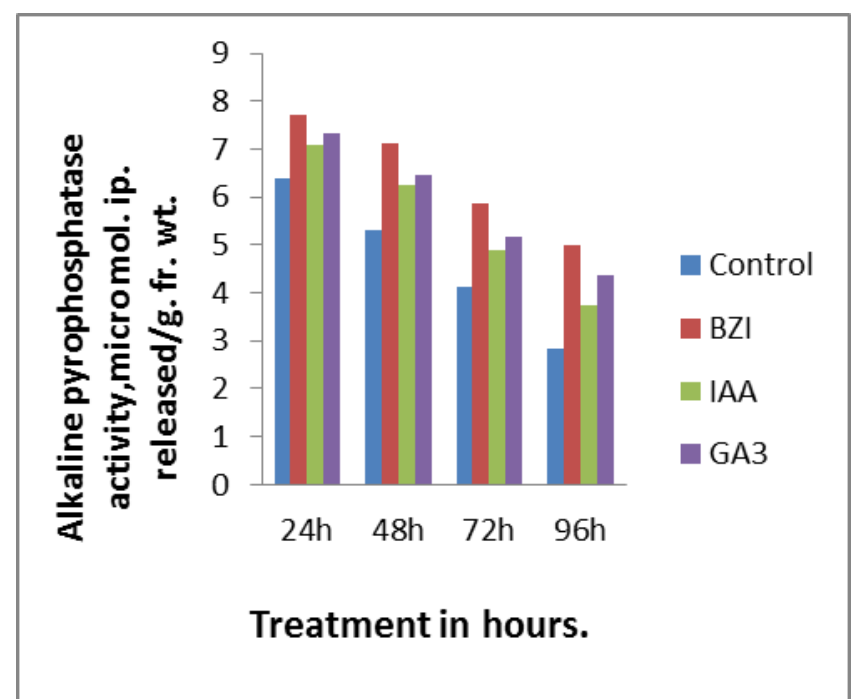

Fig. 21: Effect of Growth Regulators on Changes in Alkaline Pyro Phosphatase Activity in Excised Pennisetum Typhoides Burm. Leaves During Senescence in Dark.

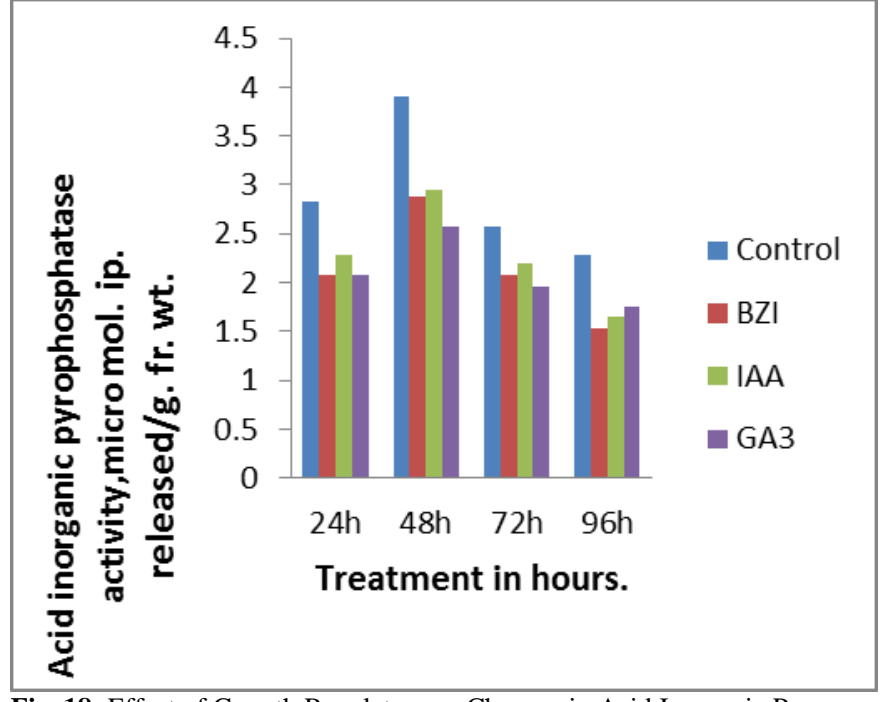

Fig. 18: Effect of Growth Regulators on Changes in Acid Inorganic Pyro Phosphatase Activity in Excised Setaria italica L. Leaves During Senescence in Light.

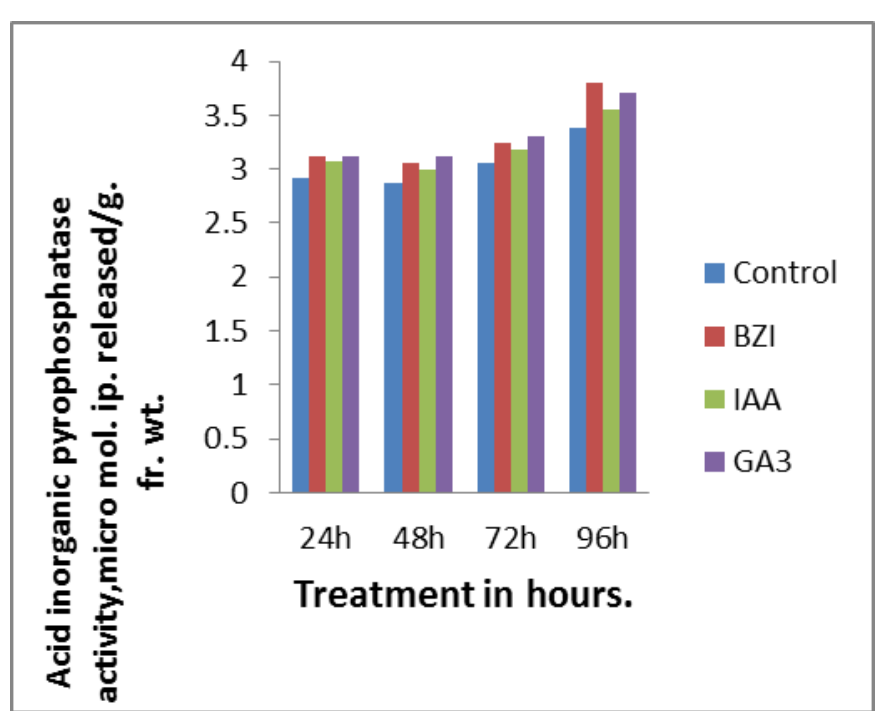

Fig. 20: Effect of Growth Regulators on Changes in Acid Inorganic Pyro Phosphatase Activity in Excised Pennisetum typhoides Burm. Leaves During Senescence in Light.

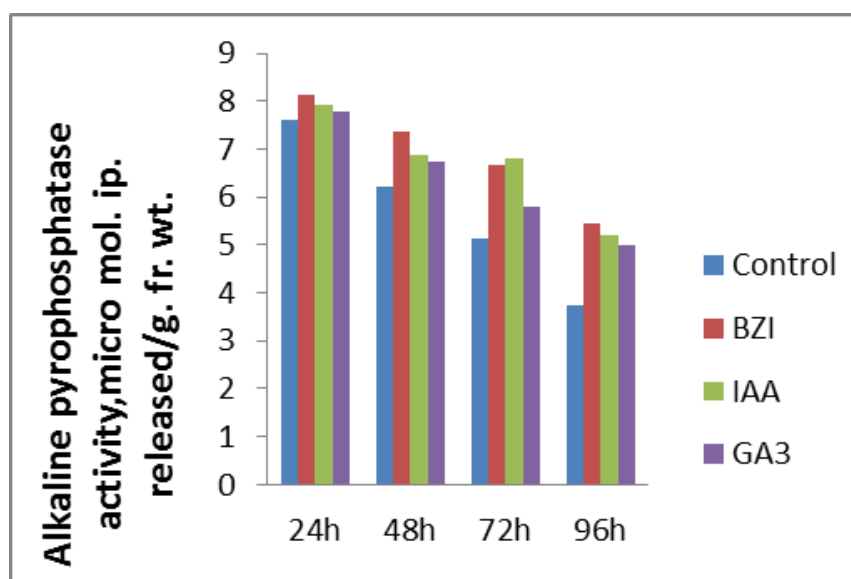

Treatment in hours.

Fig. 22: Effect of Growth Regulators on Changes in Alkaline Pyro Phosphatase Activity in Excised Pennisetum Typhoides Burm. Leaves During Senescence in Light. 


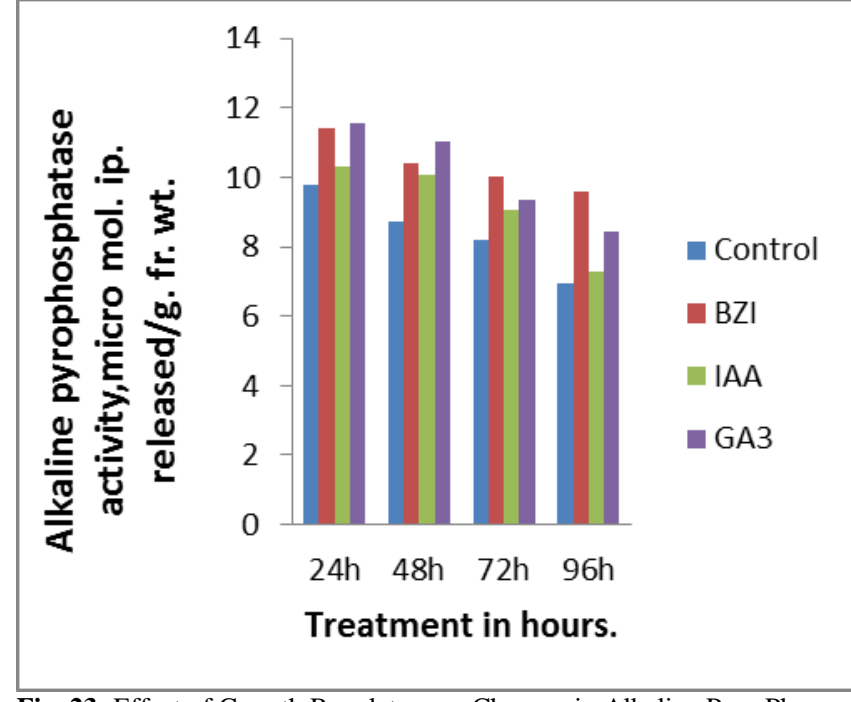

Fig. 23: Effect of Growth Regulators on Changes in Alkaline Pyro Phosphatase Activity in Excised Setaria italica L. Leaves During Senescence in Dark.

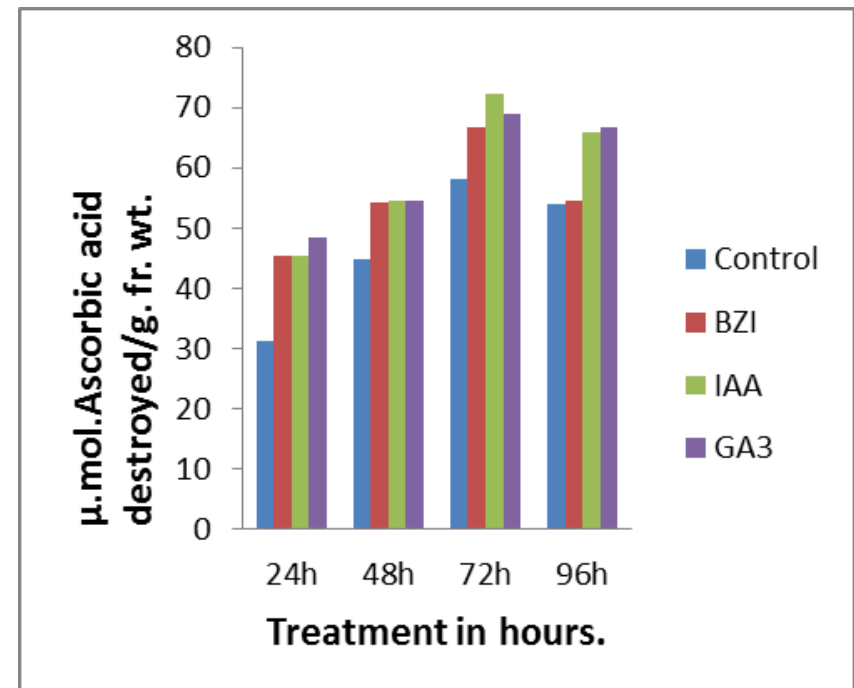

Fig. 25: Effect of Growth Regulators on Changes in Ascorbic Acid Oxidase Activity in Excised Pennisetum typhoides Burm. Leaves During Senescence in Dark.

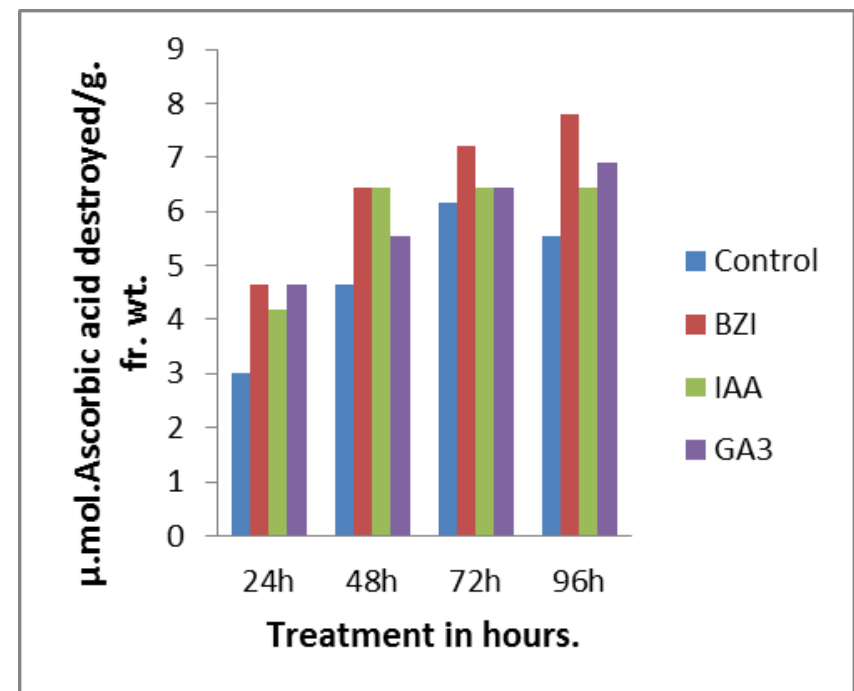

Fig. 27: Effect of Growth Regulators on Changes in Ascorbic Acid Oxidase Activity in Excised Setaria italica L. Leaves During Senescence Dark.

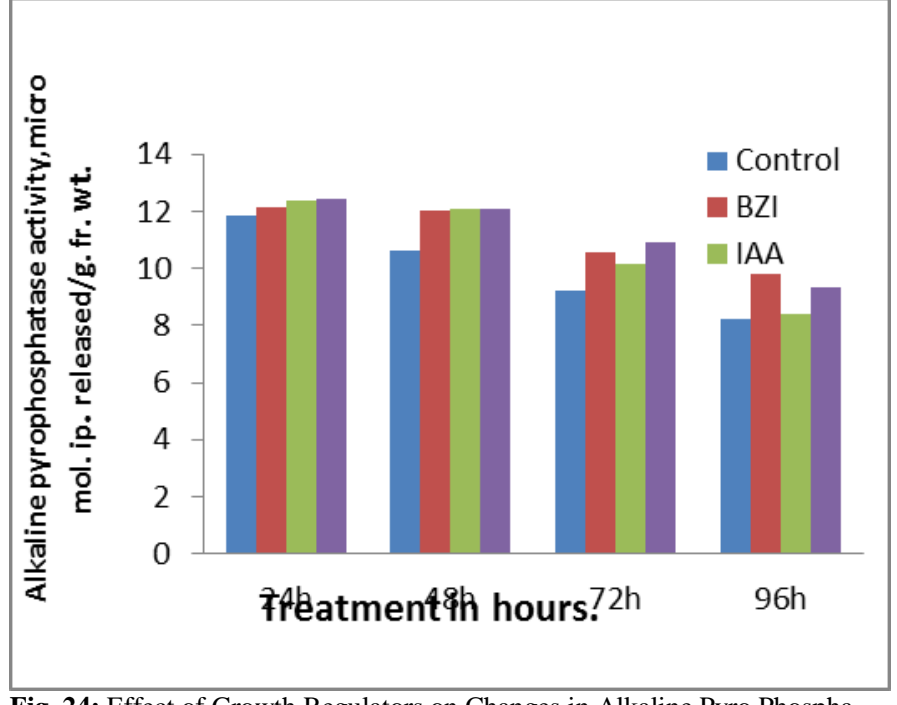

Fig. 24: Effect of Growth Regulators on Changes in Alkaline Pyro Phosphatase Activity in Excised Setaria italica L. Leaves During Senescence in Light.

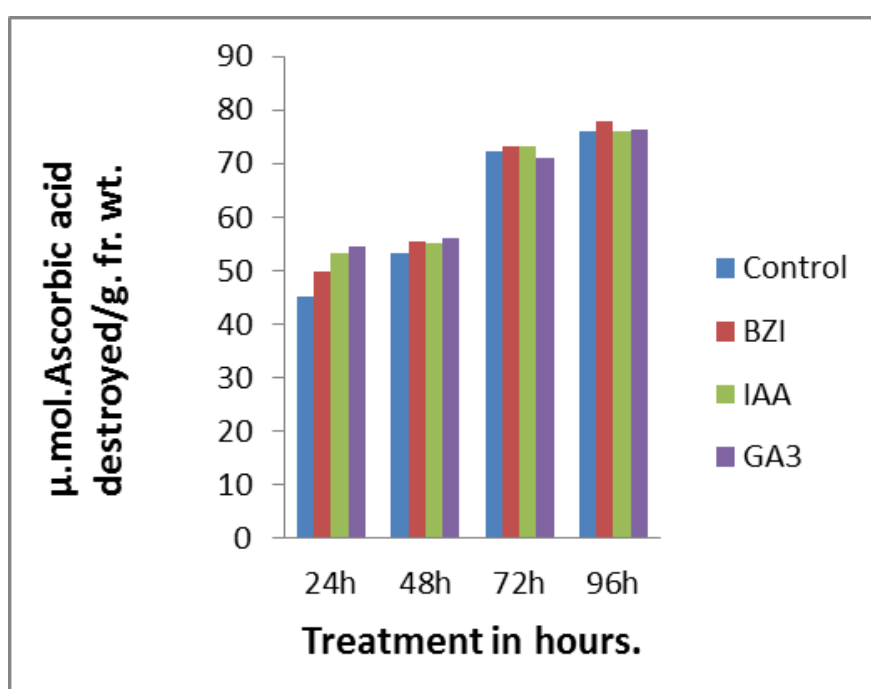

Fig. 26: Effect of Growth Regulators on Changes in Ascorbic Acid Oxidase Activity in Excised Pennisetum typhoides Burm. Leaves During Senescence Light.

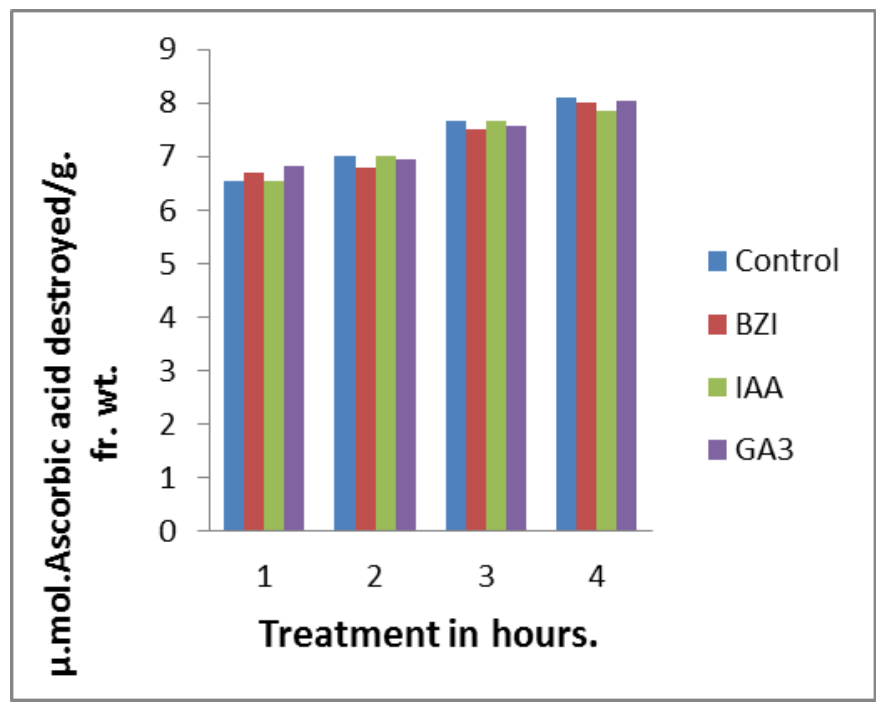

Fig. 28: Effect of Growth Regulators on Changes in Ascorbic Acid Oxidase Activity in Excised Setaria italica L. Leaves During Senescence Light. 


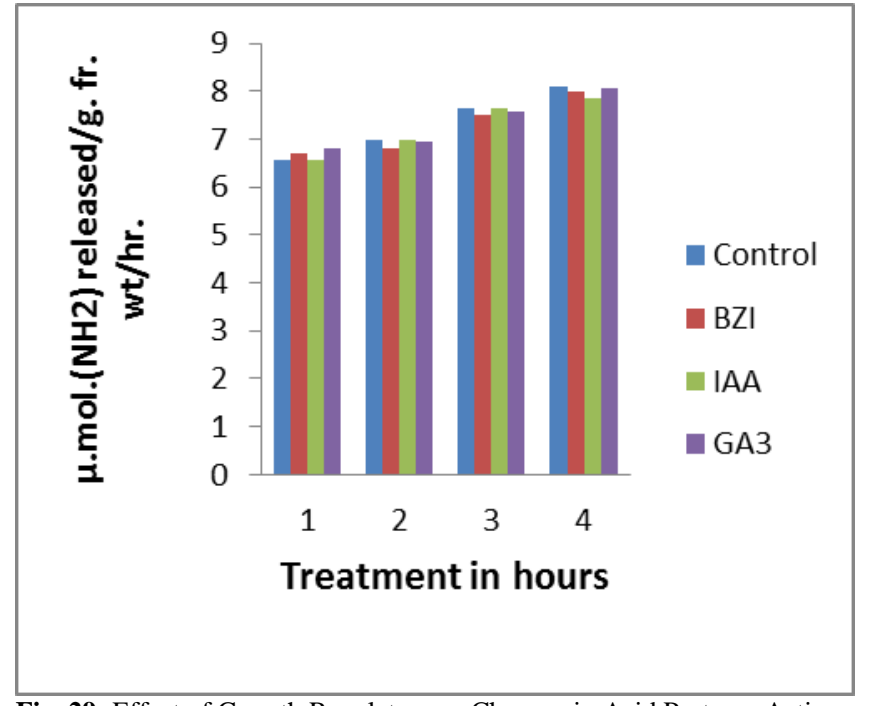

Fig. 29: Effect of Growth Regulators on Changes in Acid Protease Activity in Excised Setaria italica L. Leaves During Senescence Light.

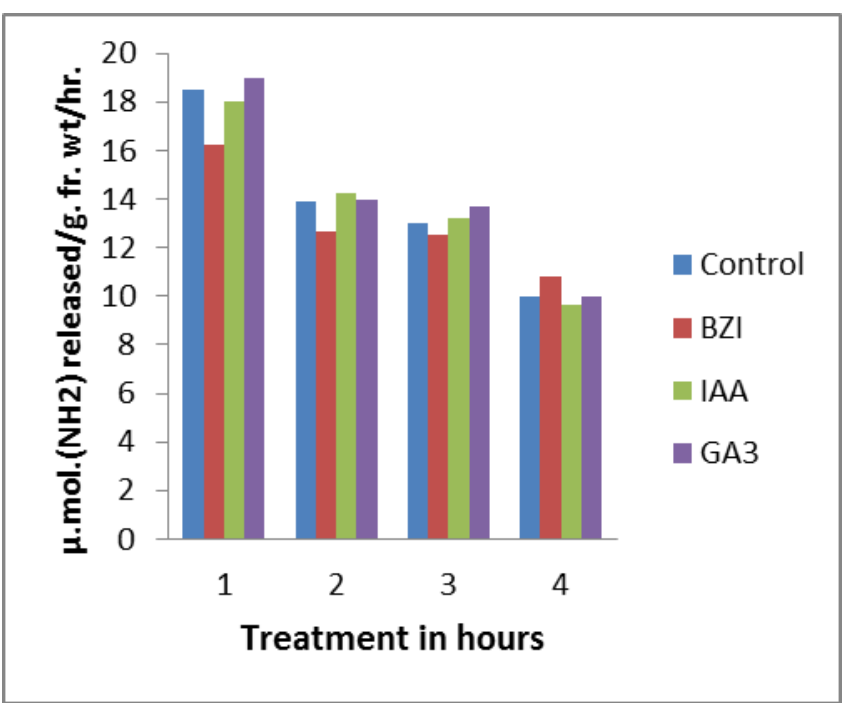

Fig. 31: Effect of Growth Regulators on Changes in Acid Protease Activity in Excised Pennisetum typhoides Burm. Leaves During Senescence in Light.

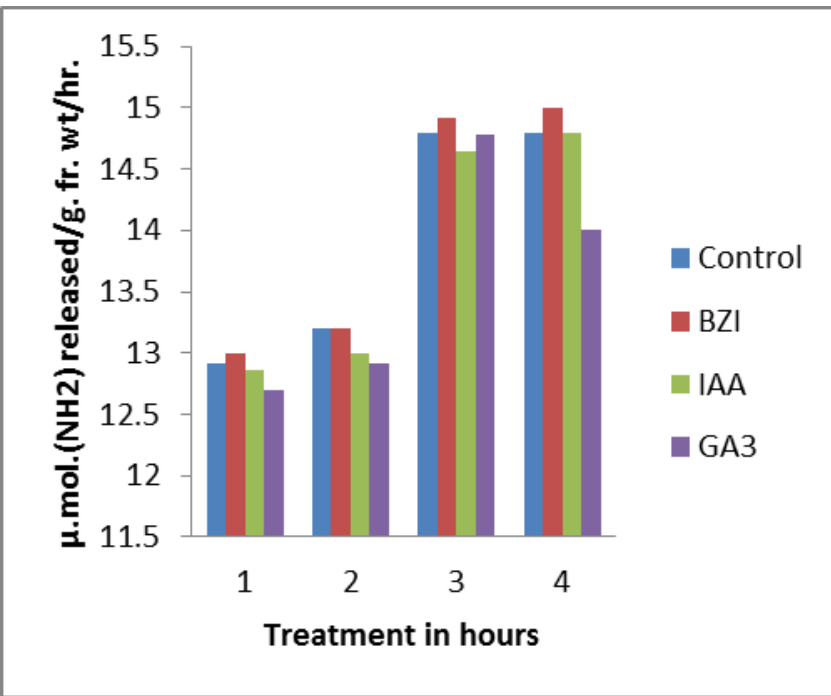

Fig. 33: Effect of Growth Regulators on Changes in Alkaline Protease Activity in Excised Setaria italica L. Leaves During Senescence in Light.

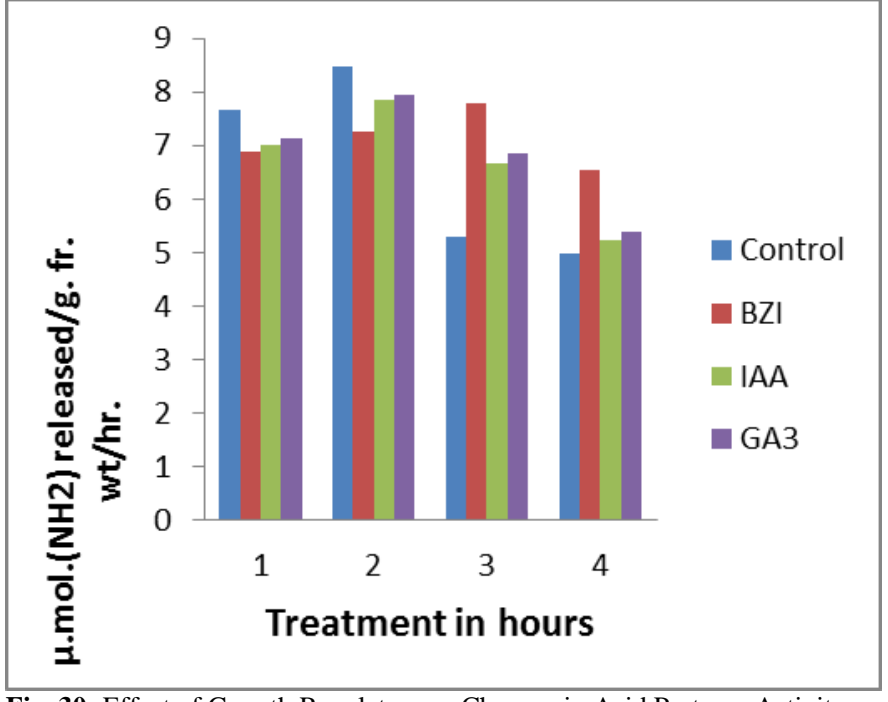

Fig. 30: Effect of Growth Regulators on Changes in Acid Protease Activity in Excised Setaria italica L. Leaves During Senescencedark.

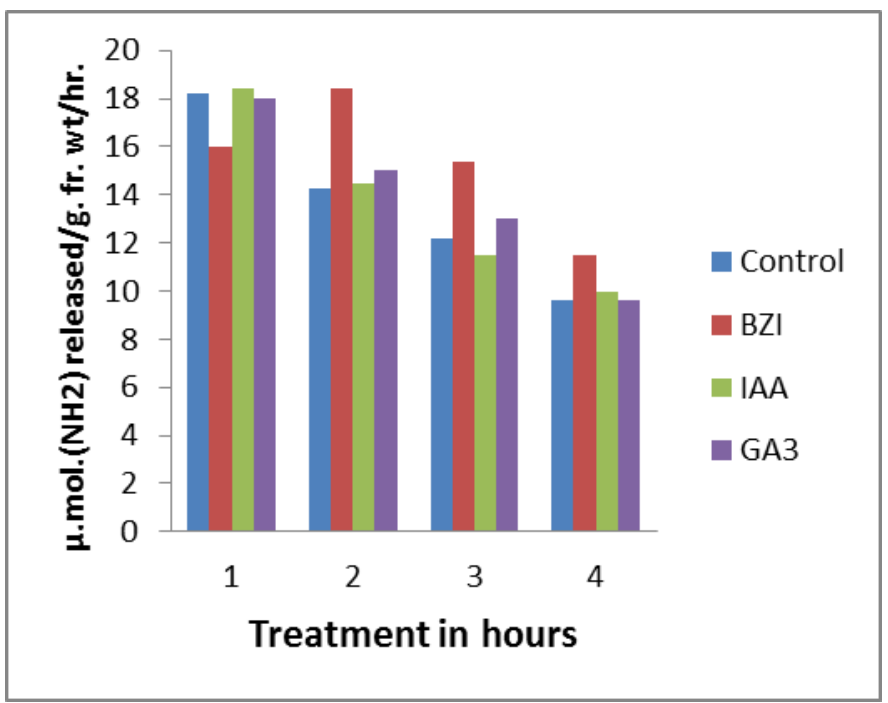

Fig. 32: Effect of Growth Regulators on Changes in Acid Protease Activity In Excised Pennisetum typhoides Burm. Leaves During Senescence in Dark.

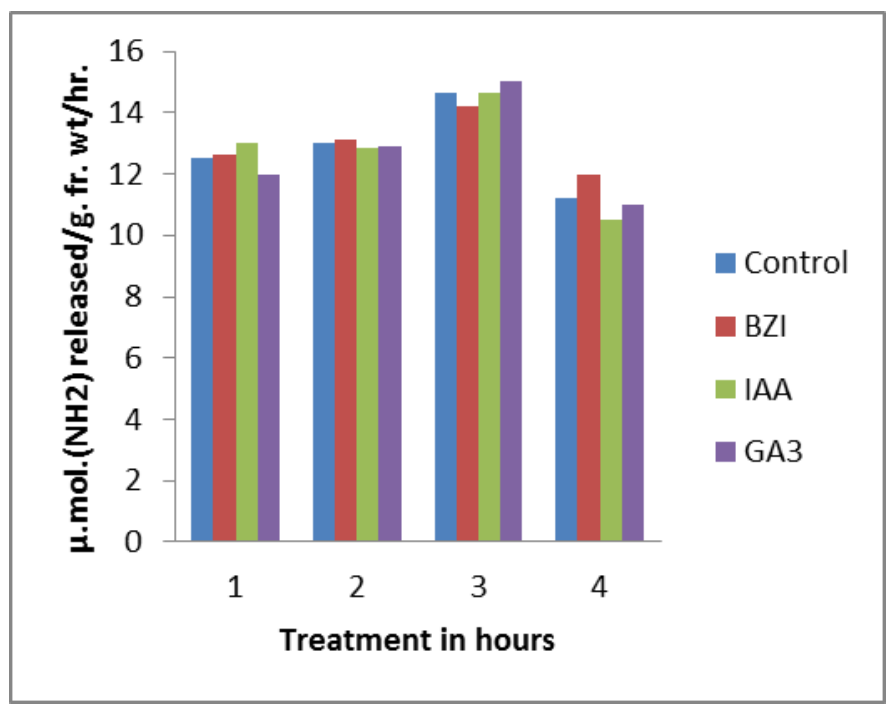

Fig. 34: Effect of Growth Regulators on Changes in Alkaline Protease Activity in Excised Setaria italica L. Leaves During Senescence in Dark. 


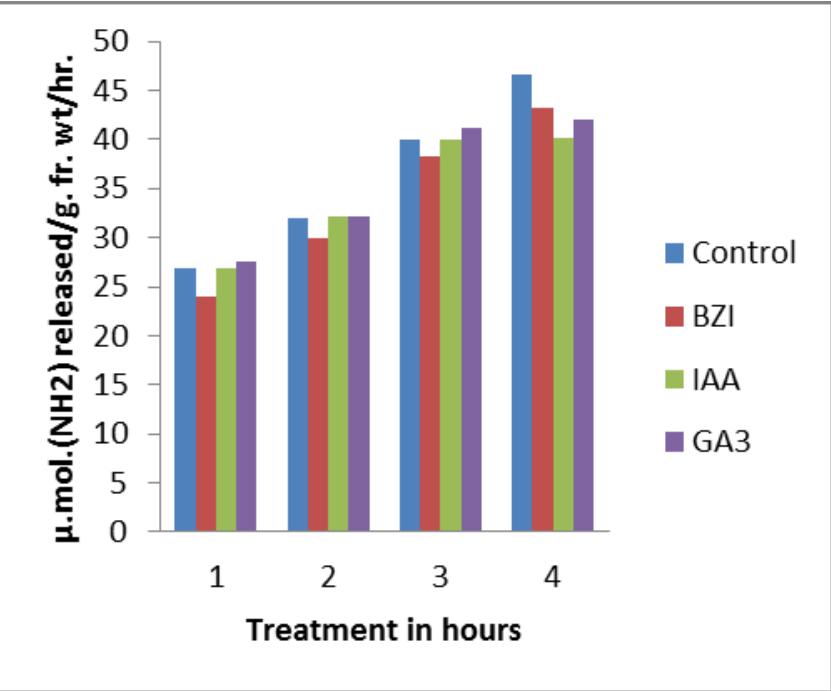

Fig. 35: Effect of Growth Regulators on Changes in Alkaline Protease Activity in Excised Pennisetum typhoides Burm. Leaves During Senescence in Light

\section{Acknowledgements}

Authors are thankful to Principal, Khallikote Autonomous College, Berhampur and HOD, Botany Department for encouragement for research activity and laboratory facilities.

\section{References}

[1] Amir, D., Goldschmidt, E.E. and Altman, A. (1987) Chlorophyl Catabolism in senescing plant tissues: in vivo break down intermediates suggest different degradative pathways for citrus -fruit and parseley leaves- Proc, Natl. Aea. Sci., USA. 1901-1905. http://dx.doi.org/10.1073/pnas.84.7.1901.

[2] Anderson, J.W. and Rowan, K.S. (1966) the effect of 6-furfury aminopurine on senescence in tobacco leaf tissue after harvest Biochem. J.98: 401-404. http://dx.doi.org/10.1042/bj0980401.

[3] Bagi, G. And Farkas, G.L. (1967) on the nature of increase in ribonuclease activity in mechanically damaged tobacco leaf tissue. phytochemistry.6: 161-169. http://dx.doi.org/10.1016/S00319422(00)82759-4.

[4] Balz, H.P. (1966) Inter cellular likalization and Funktion van hydrolytischen Enzymenbei Tabak. - planta 70: 207-236. http://dx.doi.org/10.1007/BF00396489.

[5] Beevers, L., (1968) Growth regulator control of senescence in leaf discs of Nasturtium CTropaeolum majus). In: biochemistry and physiology of plant growth substances. (F. Wightman, G. Setterffield, eds).pp.1417-1434. Runge Press, Ottawa.

[6] Beeve'rs, L (1976) Senescence. In: plant Biochemistry (J. Bonner J.E. Varner, Eds:) pp. 771-94. Academic Press, New York.

[7] Blank, A and Thomas T.A. Mc Keon (1991) Three RNase in senescent and non-senescent wheat leaves. Platnt physiol 97, 1402-1408 http://dx.doi.org/10.1104/pp.97.4.1402.

[8] Brady, C.J. (1988) Nucleic acid and protein synthesis. In Senescence and Aging in plants. (L.D. Nooden and A.C. Leopold eds.).Pp.147-171. Academic press, San Diego. http://dx.doi.org/10.1016/b978-0-12-520920-5.50011-0.

[9] De jong, D.W. (1972) Detergent extraction of enzymes from tobacco Greaves varying in maturity. - Plant physiol.50:733-37. http://dx.doi.org/10.1104/pp.50.6.733.

[10] De Leo, P. and Sacher, J.A. (1970) Control of ribonuclease and acid phosphatase by auxin and abscisic acid during senescence of Rhoeo leaf sections. - Plant physiol.46:806-11. http://dx.doi.org/10.1104/pp.46.6.806.

[11] Drazkiewiez, Maria. And Zbigniew, Krupa. (1992) the participation of in chlorophyll metabolism. Acta. Soc. Bot. Pol. 60(1-2) 139-154.

[12] Garcia, A.L. and Galindo, L. (1991) Chlorophyllase activity as biochemical indicator of manganese and iron deficiencies in Citrus. Photosynthetica 25(3): 351-357.

[13] Ellsworth, R.K., Tsuk, R.M. and St. Pierre, L.A. (1976) studies on Chlorophyllase IV Attribution of hydrolytic and esterifying chloro-

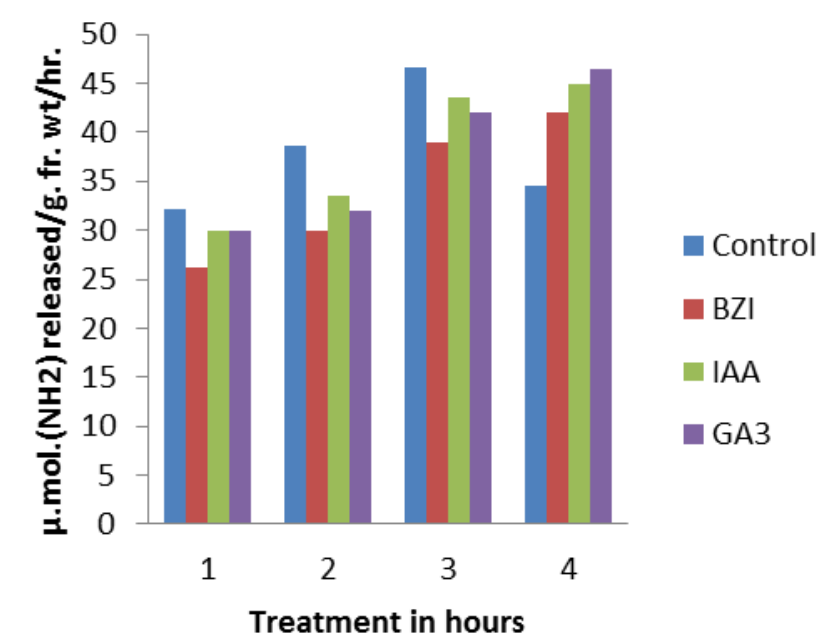

Fig. 36: Effect of Growth Regulators on Changes in Alkaline Protease Activity in Excised Pennisetum typhoides Burm. Leaves During Senescence in Dark.

phyllase activities observed in vitro to two enzymes. photosynthetica 10: 312-323.

[14] Hodge, E.T. and Sacher, J.A. (1975) Effects of kinetin auxin and abscisic acid on ribonuclease and acidphosphatase during senescence of leaf tissues. - Biochem. Physiol. Pflanzen. 168: 433-441.

[15] Holden, N. (1974) Chlorophll degradation products in leaf protein preparations. -J. Sci. Food Agric.25: 1427-32. Huang, Y. and Kao, C.H. (1991) Senescence of rice leaves: XXV changes of acid phosphatase activity Bot. Bull. Acad. Sin. (Taipet) 32: 31-42.

[16] Kar, M. and Feirabend, J. (1984) Metabolism of activated oxygen in detached wheat and rye leaves and its relevance to the initiation of senescence. - Planta - 160:385-391. http://dx.doi.org/10.1007/BF00429753.

[17] Kar, M. and Mishra, D. (1975) Inorganic pyrophosphatase activity during leaf senescence. - Gen. J. Bot. 53: 503-511. http://dx.doi.org/10.1139/b75-061.

[18] Kar, M. and Mishra, D. (1976) Catalase, peroxidase and polypheno oxidase activities during rice leaf senescence. - Plant physiol. 57: 315-318. http://dx.doi.org/10.1104/pp.57.2.315.

[19] Kenis, J; D. and Trippi, V.S. (1982) Envejeeimiento. Y abscission en Phaseolus Vulgaris 1. Actividad de fosfatase acida: en relecion con la edad y su regulacion por calidad de ja luz. Azucares Y cicloheximida. - Phyton. 42:9-16.

[20] Kumar, K.B. and Khan, P.A. (1984) Levels of deoxyribonucleic acid and of deoxyribonucleolytic activity in Ragi leaves during senescence. - Biol. Plant. 26:174-180. http://dx.doi.org/10.1007/BF02895044.

[21] Lewington, R.J., Talbot, M. and Sinson, E.W. (1967) the yellowing of attached and detached cucumber cotyledons. - J. Exp. Bot. 18: 526-634. http://dx.doi.org/10.1093/jxb/18.3.526.

[22] Mahapatra,M.(1992): Study of the exogenous hormonal regulation of leaf senescence in two millets, Setaria italica, L. and Pennisetum typhoides, Burm Ph.D thesis, Berhampur University, Berhampur, Odisha

[23] Mazumdar, Sonali. Ghosh, Sibdas. Glide, R. Bernard and Dumdroff B. Erwin (1991) Activities of cholophylloase, Polyphenol pyruvate Carboxylase and ribulose 1-5-diphosphate carboxylase on the primary leaves of soybean during senescence and drought. Physiol. Plant 81(4) 473-480. http://dx.doi.org/10.1034/j.13993054.1991.810405.x.

[24] Mc Hale, J.S. and Dove, L.D. (1968) Ribonuclease activity in tomato leaves as related to development and senescence. - New Phytol. 67:505-515. http://dx.doi.org/10.1111/j.1469-8137.1968.tb05479.x.

[25] Martin, C. and Thimann, K.V. (1972 b) the role of protein synthesis in the senescence of leaves II. The influence of amino acids on senescence. Plant. http://dx.doi.org/10.1104/pp.50.4.432.

[26] Martin, C. and Thimann, K.V. (1972a) the role of protein synthesis in the senescence of leaves I. The formation protease. -Plant Physiol. 64-71. http://dx.doi.org/10.1104/pp.49.1.64.

[27] Meyer, R. and Wagner, K.G. (1986) Physiol. Plant. 67: 666. Moll, W.A., Wit, B. and Lutter, K. (1978) chlorophyllase activity in de- 
$\begin{array}{llll}\text { veloping } & \text { leaves. } & \text { - } & \text { Planta }\end{array}$ http://dx.doi.org/10.1038/174593a0.

[28] Naganna, B. and Sripathi, C.E. (1954) Pyrophosphatases in Plants during growth. - Nature 174:594-598.

[29] Naganna, B., Vegugopal, B. and Sripathi, C.E. (1955b) Occurrence of alkaline pyrophosphatase in vegetable tisssus. Biochem. J. 60:224-225. http://dx.doi.org/10.1042/bj0600224.

[30] Parrida, R.K. and Mishra, D. (1980) Acid phosphatase and adenosine triphosphate activities during rice leaf development and senescences. - Photosynthetica 14:431-136.

[31] Parida, R.K., Kar, M. and Mishra, D. (1981) Enzymatic change in gourd (Cucurbita maxima andbean (Phaseolus vulgaris) cotyledons during ageing and the effect of detopping. Boil. Plant. 23: 2937 2941.

[32] Peoples, M.B. and Dalling, M.J. (1988) the interplay between proteolysis and amino acid metabolism during senescence and nitrogen reallocation. In: Senescence and ageinin plants. (L.D.

[33] Nooden and A.C. Leopold, Eds.) pp. 182-212. Academic oress, New York.

[34] Rudiger, W., Benz, J., Guthoff, C. (1980): Detection and partial characterization of activity of chlorophyll synthetase in etioplast membranes. - Eur. J. Biochem. 109: 193-200. http://dx.doi.org/10.1111/j.1432-1033.1980.tb04784.x.

[35] Sabater B. and Rodriguez, M.T. (1978) Control of chlorophyll degradation in detached leaves of barley and oat through effect of kinetin on chlorophyllase levels. Physiol. Plant. 43:274-276. http://dx.doi.org/10.1111/j.1399-3054.1978.tb02577.x.

[36] Simon, E.W. (1967) Types of leaf senescence. - In Symp. Soc. Exp. Biol, pp. - 215-230. Cambridge Univ. Press, London.

[37] Simons, S. and Butler, L.G. (1969) alkaline inorganic pyrophosphatase of maize leaves. Biochem. Biophys. Acta.172: 150-157. http://dx.doi.org/10.1016/0005-2728(69)90100-5.

[38] Simpson, K.L., Lee, T.C., Rodriguez, D.B. and chichester, C.O. (1976) Metabolism in senescent and stored tissues. In: chemistryand Biochemistry of. Plant Pigments. Vol.I (T.W. Goodwin, Ed.)pp 779-842. Academic Press, New York.

[39] Srivastava, B.I.S. and Ware, G. (1965) the effect of kinetin on nucleic acid and nucleases in excised barley leaves. Plant Physiol. 40:62-64. http://dx.doi.org/10.1104/pp.40.1.62

[40] Sodek, L. and Wright, S.T.C. (1969) Effect of Kinetin on ribonuclease, acid phosphatase, Lipase and esterase levels in detached wheat leaves. Photochemistry 8: 1629-1640. http://dx.doi.org/10.1016/S0031-9422(00)85947-6.

[41] Sudhakar, C. Reddy, P.S. and Veeranjanejulu, K. (1991) change in respiration, its allied enzymes, pigment composition, chlorophyllase arid Hill reaction activity of horsegram seedlings under salt stress. Indian J. Plant. Physiol;34(2)171-177

[42] Thomas, H. (1987) Sid. a Mendelian locus controlling thylakoid membrance disassembly in senescing leaves Fe stucapratensis Theoreticalapp.

[43] Thomas, H., Bortelik, K., Rentsch, D., Schellenlarg, M. and Matile, P. (1989) Catabolism of chlorophyll in vivo: significance of polar chlorophyll catabolites in a non-yellowing senescence mutant of, Festuca Pratensis Huds. New Phytol. 111: 3-8. http://dx.doi.org/10.1111/j.1469-8137.1989.tb04211.x.

[44] Thompson, J.C., Legge, R.L. and Braber, R.F. (1987) the roles of free radicals in senescence and wounding. New phytol. 105: $317-$ 344. http://dx.doi.org/10.1111/j.1469-8137.1987.tb00871.x.

[45] Udvardy, J., Farkas, G.L., Marre, E. and Forti, G. (1967) the effects of sucrose and light on the level of soluble and particle bound ribonuclease activities in excised Avena leaves- physiol. Plant. 20: 781 $-788$

[46] Truelsen, T.A. (1967) Indole acetic acid - induced decreases of the ribonuclease activity in vivo Physiol, Plant.20: 1112-1119.

[47] Upadhyaya, A., Davies, T.D., Sankla, D., Sankla, N. and azmith, B.N. (1985) Effects of padobutrazol on the activities of proteolytic enzyme and $\backslash$ RNase. In Soybean leaves during senescence.-Comp. Physiol. Ecol. 10: 49-54.

[48] Van der Valk, Hendry, C.P.M. and Van Loon, L.C (1988) subcellular localisation of proteases in developing leaves of oats. (Avena sativa) Plant Physiol. 87:536-541. http://dx.doi.org/10.1104/pp.87.2.536.

[49] Woolhouse, H.W. (1978) Senescence process in the life cycle of flowering plants. - Biosciences 28: 25-31. http://dx.doi.org/10.2307/1307483. 